2016

\title{
Early Caddo Period Ceramic Vessels from the Roger D. Simmos Site (41TT321), Titus County, Texas
}

Timothy K. Perttula

Heritage Research Center, Stephen F. Austin State University

Follow this and additional works at: https://scholarworks.sfasu.edu/ita

Part of the American Material Culture Commons, Archaeological Anthropology Commons, Environmental Studies Commons, Other American Studies Commons, Other Arts and Humanities Commons, Other History of Art, Architecture, and Archaeology Commons, and the United States History Commons

Tell us how this article helped you.

This Article is brought to you for free and open access by the Center for Regional Heritage Research at SFA ScholarWorks. It has been accepted for inclusion in Index of Texas Archaeology: Open Access Gray Literature from the Lone Star State by an authorized editor of SFA ScholarWorks. For more information, please contact cdsscholarworks@sfasu.edu. 


\section{Early Caddo Period Ceramic Vessels from the Roger D. Simmos Site (41TT321), Titus County, Texas}

\section{Creative Commons License}

\section{(c) (1) \&}

This work is licensed under a Creative Commons Attribution-NonCommercial 4.0 International License 


\title{
Early Caddo Period Ceramic Vessels from the Roger D. Simmos Site (41TT321), Titus County, Texas
}

\author{
Timothy K. Perttula
}

\section{INTRODUCTION}

The Roger D. Simmons site (41TT321) is in the Sulphur River basin in East Texas. A single ancestral Caddo burial was exposed in 1984 during the removal of sand from the site for the construction of a school in Talco, Texas. Associated with the burial were three ceramic vessels—documented herein-as well as a large (ca. $18 \mathrm{~cm}$ in length) chipped stone bifacial tool made from non-local chert (identified as Edwards formation chert on the site form), an adze, and a celt.

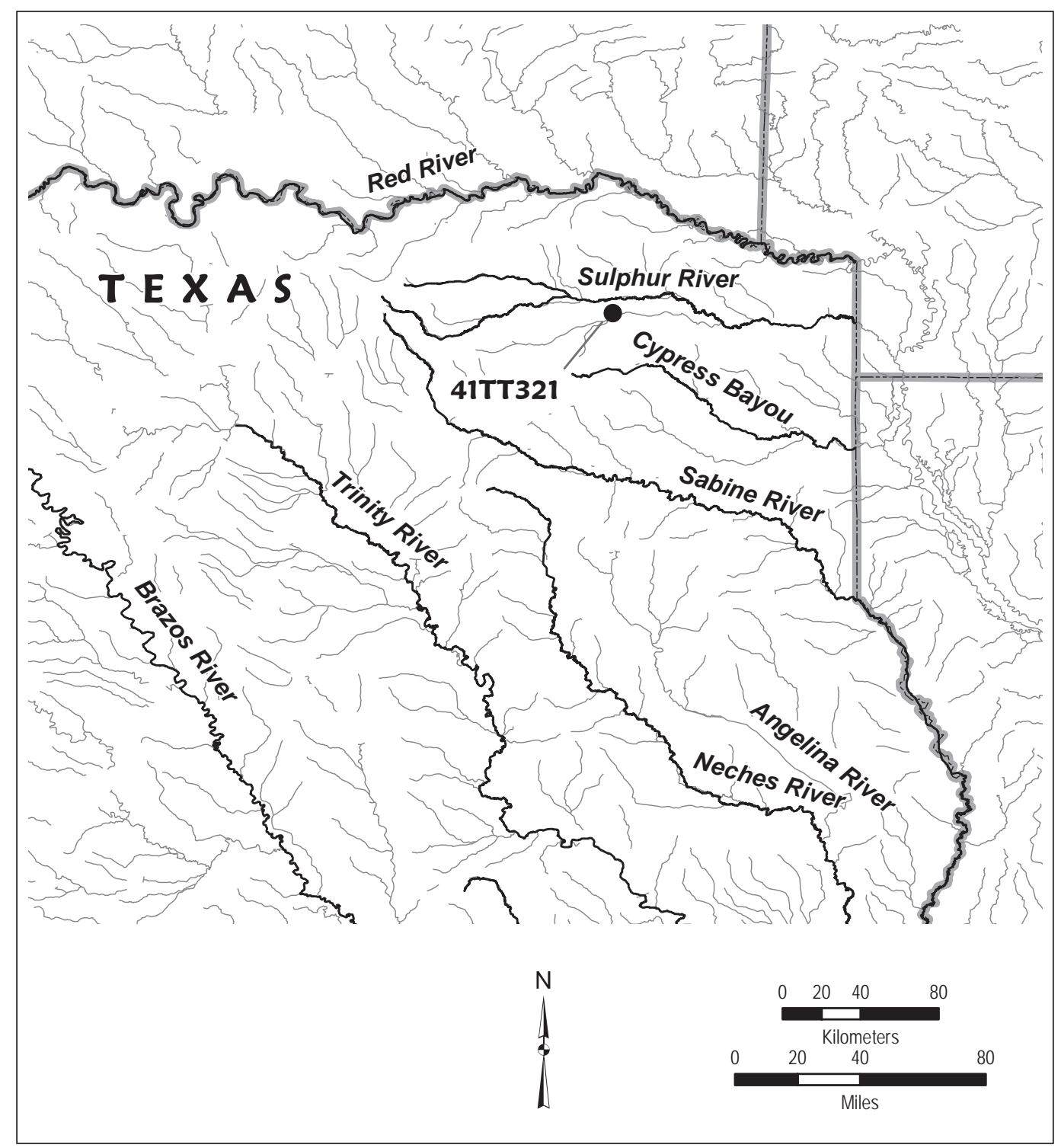

Figure 1. Location of the Roger D. Simmons site (41TT321) in East Texas. 


\section{Vessel Documentation}

There are three vessels or vessel sections in the collections from the Roger D. Simmons site (41TT321) at the Texas Archeological Research Laboratory at the University of Texas at Austin (TARL). They were donated to TARL in 1984 by Mr. Gary Sykes.

SITE NAME OR SITE NUMBER: 41TT321

VESSEL NO.: 1

VESSEL FORM: Bowl (represented by 29 sherds, 12 of which are conjoined)

NON-PLASTICS AND PASTE: grog and bone RIMANDLIPFORM: Direct rim and rounded lip

CORE COLOR: $\mathrm{F}$ (fired in a reducing environment and cooled in the open air)

INTERIOR SURFACE COLOR: reddish-brown

EXTERIOR SURFACE COLOR:

reddish-brown; fire clouds on the rim and body

WALL THICKNESS (IN MM):

rim, $5.0 \mathrm{~mm}$; body, $5.6 \mathrm{~mm}$

INTERIOR SURFACE

TREATMENT: smoothed

EXTERIOR SURFACE

TREATMENT: smoothed

HEIGHT (IN CM): N/A

ORIFICE DIAMETER (IN CM): N/A

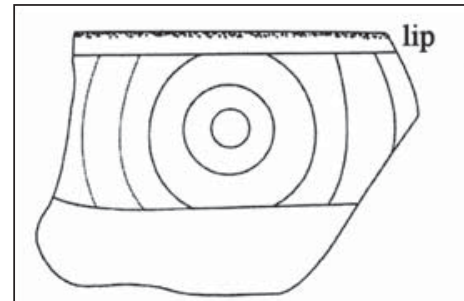

a
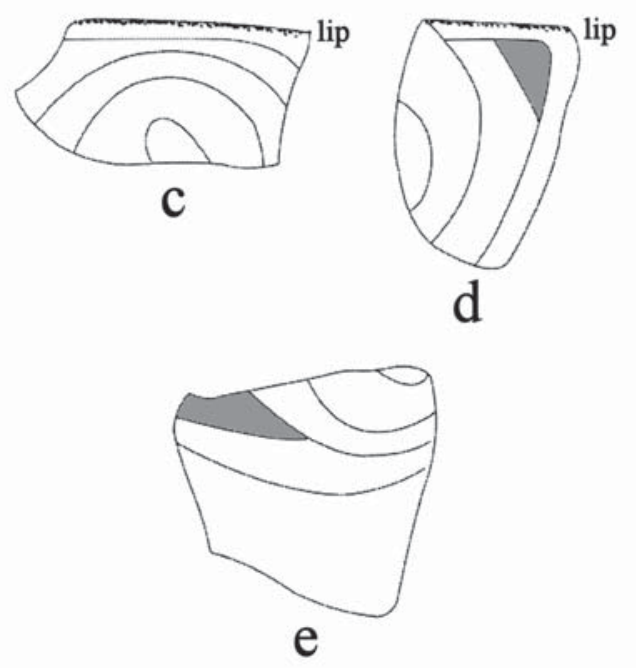

Figure 2. Decorative elements on Holly Fine Engraved rim and body sherds from 41TT321.

DIAMETER AT BOTTOM OF RIM

OR NECK (IN CM): N/A

BASE DIAMETER (IN CM) AND SHAPE OF BASE: N/A

ESTIMATED VOLUME (IN LITERS): N/A

DECORATION (INCLUDING MOTIF AND ELEMENTS WHEN APPARENT): The vessel rim has an unknown number of fine-line engraved concentric semi-circles and circles, with triangular-shaped excised areas at the outer corners of the concentric semi-circles (Figure 2).

PIGMENT USE AND LOCATION ON VESSEL: red pigment in the engraved lines

TYPE AND VARIETY (IF KNOWN): Holly Fine Engraved (see Suhm and Jelks 1962:Plate 40f) 
SITE NAME OR SITE NUMBER: 41TT321

VESSEL NO.: 2

VESSEL FORM: Square bowl with rim peaks

NON-PLASTICS AND PASTE: grog

RIM AND LIP FORM: Direct and exterior thickened rim and rounded lip

CORE COLOR: F (fired in a reducing environment and cooled in the open air)

INTERIOR SURFACE COLOR: yellowish-brown; fire clouds on the body

EXTERIOR SURFACE COLOR: yellowish-brown; fire clouds on the rim, body, and base

WALL THICKNESS (IN MM): rim, $5.5 \mathrm{~mm}$; body, $7.9 \mathrm{~mm}$; base, $8.6 \mathrm{~mm}$

INTERIOR SURFACE TREATMENT: smoothed

EXTERIOR SURFACE TREATMENT: smoothed

HEIGHT (IN CM): 7.7

ORIFICE DIAMETER (IN CM): 10.5

DIAMETER AT BOTTOM OF RIM OR NECK (IN CM): N/A

BASE DIAMETER (IN CM) AND SHAPE OF BASE: 7.0; square and rounded

ESTIMATED VOLUME (IN LITERS): 0.3

DECORATION (INCLUDING MOTIFAND ELEMENTS WHENAPPARENT): The upper part of the vessel has three horizontal engraved lines; the rim peaks have engraved concentric semi-circles. The remainder of the vessel has at least two, but probably four, engraved concentric circles nestled between concentric semi-circular lines. One of these lines has an excised triangle element pendant from the end of the engraved line (Figure 3).

PIGMENT USE AND LOCATION ON VESSEL: none

TYPE AND VARIETY (IF KNOWN): Spiro Engraved (see Suhm and Jelks 1962:Plate 74e)

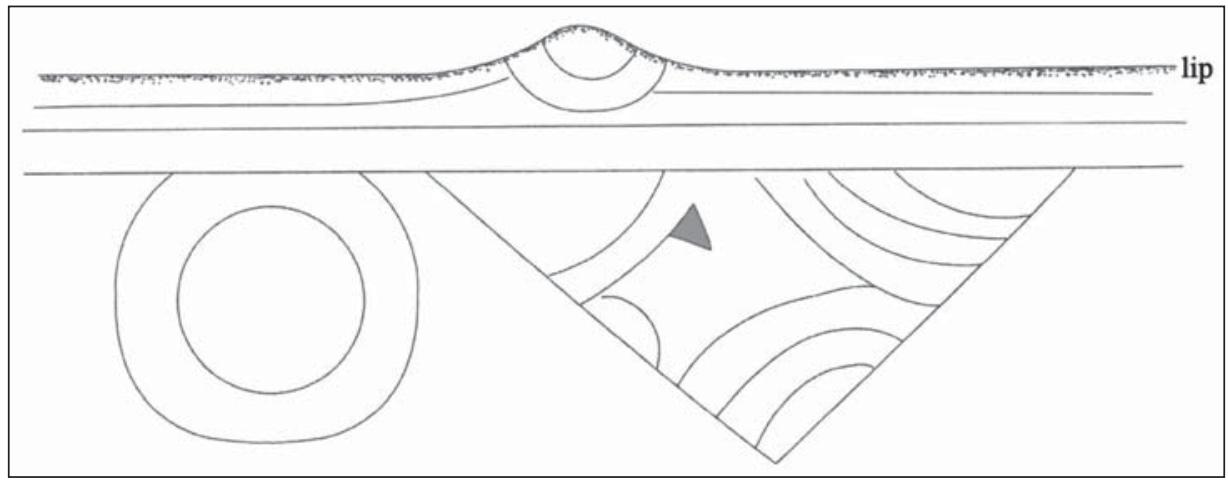

Figure 3. Decorative elements on Spiro Engraved vessel section from 41TT321. 
SITE NAME OR SITE NUMBER: 41TT321

VESSEL NO.: 3

VESSEL FORM: Jar

NON-PLASTICS AND PASTE: grog

RIM AND LIP FORM: Direct rim and flat lip

CORE COLOR: $\mathrm{H}$ (fired in a reducing environment and cooled in the open air)

INTERIOR SURFACE COLOR: yellowish-brown; fire clouds on the rim

EXTERIOR SURFACE COLOR: dark grayish-brown; fire clouds on the rim, body, and base

WALL THICKNESS (IN MM): rim, $4.2 \mathrm{~mm}$

INTERIOR SURFACE TREATMENT: smoothed

EXTERIOR SURFACE TREATMENT: burnished

HEIGHT (IN CM): 8.9

ORIFICE DIAMETER (IN CM): 7.1

DIAMETER AT BOTTOM OF RIM OR NECK (IN CM): 6.8

BASE DIAMETER (IN CM) AND SHAPE OF BASE: 5.1; circular and flat

ESTIMATED VOLUME (IN LITERS): 0.4

DECORATION (INCLUDING MOTIF AND ELEMENTS WHEN APPARENT): The vessel rim has five horizontal engraved lines. The vessel body is decorated with four alternate sets of engraved concentric circles (four or five concentric semi-circular lines), and the innermost semi-circle is excised (Figure 4).

PIGMENT USE AND LOCATION ON VESSEL: red pigment in the engraved lines

TYPE AND VARIETY (IF KNOWN): Holly Fine Engraved

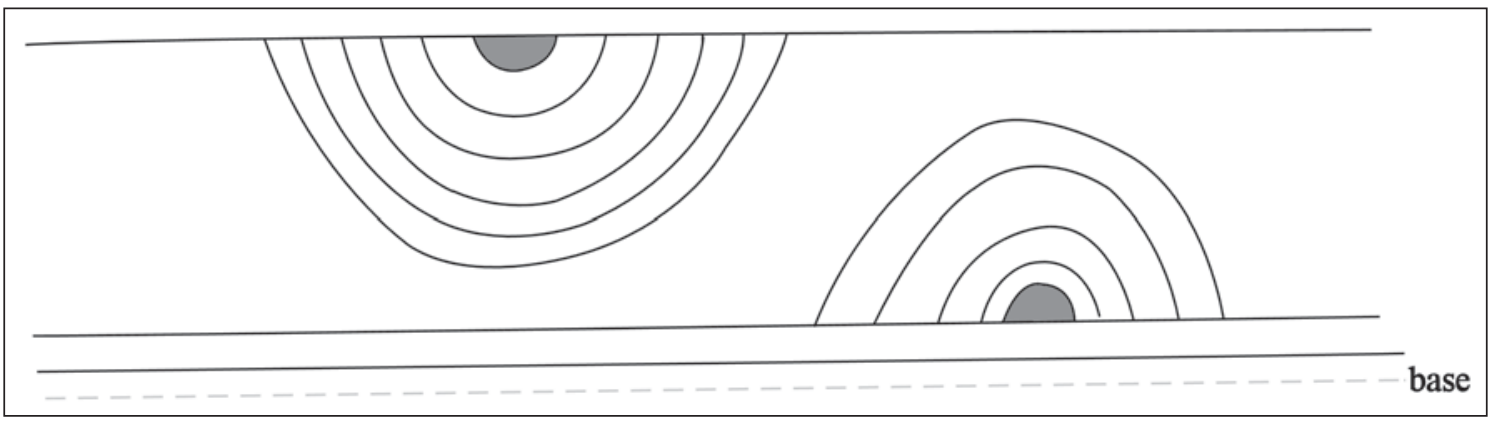

Figure 4. Decorative elements on body of Holly Fine Engraved vessel section from 41TT321. 


\section{SUMMARY AND CONCLUSIONS}

The three ceramic vessels from 41TT321 are from an Early Caddo period (ca. A.D. 1000-1200) burial context. They include a small Spiro Engraved bowl with rim peaks and two small Holly Fine Engraved vessels: a bowl and a jar. The vessels are tempered with grog (67 percent) and grog-bone (33 percent).

\section{REFERENCES CITED}

Suhm, D. A. and E. B. Jelks (editors)

1962 Handbook of Texas Archeology: Type Descriptions. Special Publication No. 1, Texas Archeological Society, and Bulletin No. 4, Texas Memorial Museum, Austin. Reprinted in 2009, Gustav's Library, Davenport, Iowa. 